\title{
Storage Time and Amendments Affect Pine Tree Substrate Properties and Marigold Growth
}

\author{
Linda L. Taylor ${ }^{1}$, Alexander X. Niemiera, Robert D. Wright, \\ and J. Roger Harris \\ Department of Horticulture, Virginia Polytechnic Institute and State \\ University, 301 Saunders Hall, Blacksburg, VA 24061
}

Additional index words. $\mathrm{pH}$, cation exchange capacity, electrical conductivity, carbon-tonitrogen ratio, bulk density, particle size distribution, Pinus taeda, loblolly pine, Tagetes erecta 'Inca Gold'

Abstract. Pine tree substrate (PTS) is a relatively new alternative to the commonly used pine bark and peat-based substrates for container crop production. Physical and chemical properties of freshly manufactured PTS have been studied; however, this new substrate will sometimes be manufactured and stored for later use by growers. The objective of this research was to determine how chemical and physical properties of PTS were affected by storage duration with or without amendments of limestone or peatmoss. We also studied how the growth of marigold was influenced by PTS storage time and by lime and peat amendments. Substrate properties studied were $\mathbf{p H}$, cation exchange capacity (CEC), electrical conductivity (EC), carbon-to-nitrogen ratio (C:N), bulk density (BD), and particle size distribution. Pine tree substrate was manufactured by hammermilling chips of $\approx 15$-year-old loblolly pine trees (Pinus taeda L.) through two screen sizes, $4.76 \mathrm{~mm}$ (PTS) and $15.9 \mathrm{~mm}$ [amended with peat (PTSP)]. Pine tree substrate and PTSP were amended with lime at five rates and a peat-perlite mix (PL) served as a control treatment. Substrates were prepared, placed in plastic storage bags, and stored on shelves in an open shed in Blacksburg, VA. Substrates were subsampled at $1,42,84,168,270$, and 365 days after storage. At each subsampling day, twelve 1-L containers were filled with a subsample of each treatment. Six of the 12 were left fallow and six were planted with 14-day-old marigold (Tagetes erecta L. 'Inca Gold') seedlings. Substrate was also collected for analysis of CEC, C:N, BD, and particle size distribution. The $\mathrm{pH}$ of non-limed PTS decreased during storage, and at least $1 \mathrm{~kg} \cdot \mathrm{m}^{-3}$ lime was needed to maintain PTS pH 5.4 or greater over the 365-day storage period (Day $1 \mathrm{pH}=$ 5.8) and 2 to $4 \mathrm{~kg} \cdot \mathrm{m}^{-3}$ was needed to maintain PTSP pH 5.4 or greater for 365 days (Day $1 \mathrm{pH}=5.2)$. EC measurements were highest at Day $1\left(1.02\right.$ to $\left.1.21 \mathrm{dS} \cdot \mathrm{m}^{-1}\right)$ in all treatments and decreased by Day 42. Cation exchange capacity decreased over time in non-limed PTS and PTSP. Carbon-to-nitrogen ratio and BD remained the same over time for all treatments. There were minor changes in particle size distribution for limed PTS. Marigold growth in all limed PTS and PTSP treatments was equal to or greater than in PL, except at Day 1; the lower growth in PTS and PTSP at Day 1 compared with PL suggests that freshly manufactured PTS may contain a phytotoxic substance that was not present in PTS by Day 42. Pine tree substrate and PTSP are relatively stable when stored as described previously, except for a $\mathrm{pH}$ decrease that can be prevented with additions of lime before storage.

Pine bark and peatmoss are widely used substrates for container-grown crops in the greenhouse and nursery industries. There have

\footnotetext{
Received for publication 1 Aug. 2012. Accepted for publication 16 Oct. 2012 .

The research was funded in part by the Virginia Agricultural Council and the Virginia Nursery and Landscape Association.

The technical assistance of Velva Groover is gratefully acknowledged.

This article is a chapter of a submitted dissertation by Linda L. Taylor for the degree of Ph.D. in Horticulture.

Use of trade names does not imply endorsement of the products named nor criticism of similar ones not mentioned.

${ }^{1}$ To whom reprint requests should be addressed; e-mail 1ltaylor@vt.edu.
}

been many recent research reports on the development of alternative soilless substrates. This research stems from the increasing cost in addition to decreasing availability of pine bark and the cost and sustainability of peatmoss mining. A wide variety of materials has been investigated and wood-based substrates show promise as alternatives to peatmoss and pine bark. Several of these wood-based substrates are from coniferous species (softwoods) and are produced from chipped and ground trunks (with bark; termed PTS; Wright et al., 2006); chipped and shredded trunks with low bark amounts (Gruda and Schnitzler, 2004; Gumy, 2001); whole shoot portions (needles, limbs, bark and trunk; termed WholeTree ${ }^{\circledR}$; Fain et al., 2006, 2008a); or wood, bark, foliage, and other materials [remains from in-field chipping operations for the paper industry; termed clean chip residual (CCR); Boyer et al., 2008]. Cost, availability, and sustainability issues of bark and peat substrates can be bypassed by using these substrate alternatives. These wood-based substrates can be produced from tree species that are native to wide geographic ranges and can be grown specifically for this purpose, harvested, and replenished locally.

Softwood-based substrates have been shown to be suitable for at least some horticultural crop species and produce plant growth that is similar to, or greater than, plants grown in pine bark or peatmoss (Boyer, 2009; Fain et al., 2008b; Gruda and Schnitzler, 2004; Wright et al., 2008). In these studies, substrate particle size and effects of amendments such as lime, peat, pine bark, and sand were investigated. Fertilizer regimes have also been investigated because nitrogen $(\mathrm{N}) \mathrm{im}$ mobilization can decrease plant-available $\mathrm{N}$ in uncomposted wood substrates. Research has shown that a higher $\mathrm{N}$ application rate for some wood-based substrates is required to compensate for immobilized $\mathrm{N}$ compared with $\mathrm{N}$ application rates for conventional substrates (Gruda et al., 2000; Jackson et al., 2008a, 2008b; Wright et al., 2008). However, Boyer et al. (2012) have reported that $\mathrm{N}$ immobilization in CCR is similar to that in pine bark and therefore can be fertilized similarly. In nearly all of these studies, substrates were manufactured just before use or, in a few cases, stored for up to $144 \mathrm{~d}$. However, substrate manufacturers and growers may store these substrates for later sale or use, and research on the effects of wood-based substrate storage is needed.

Few studies have investigated the effects of storage on wood-based substrate properties and plant growth. Kostov et al. (1991) investigated the decomposition of composted sawdust and pine bark on microorganism activity $\left(\mathrm{CO}_{2}\right.$ evolution, ammonification, nitrification) and density. Dickinson and Carlile (1995) conducted a study on combinations of composted pine and spruce bark and chipboard and paper waste. Neither of these aforementioned studies used uncomposted and untreated wood constituents.

Gaches et al. (2011) found that dry weight, growth index, and bloom count of Tagetes patula L. 'Little Hero' marigold and Petunia $\times$ hybrida Vilm. 'Dreams White' petunia were higher in a ground pine tree, peat substrate $(1: 1, \mathrm{v}: \mathrm{v})$ that was aged for 94 and $169 \mathrm{~d}$ than in those produced in the same substrate that was recently manufactured. The authors suggest differences in air space and container capacity, rate of $\mathrm{N}$ immobilization, and the presence of an allelopathic chemical in recently manufactured substrate as explanations for growth differences. A pH decrease has been observed in both stored PTS and loblolly pine logs (R. Wright, unpublished data) indicating that PTS may need lime amendment. Lime addition to wood-based substrates, similar to additions to bark and peat substrates, neutralizes protons. Lime amendment is suggested when PTS is amended with peat (Jackson 
et al., 2009a) as a result of the acidifying nature of peat.

The objective of this work was to determine the effects of storage time on PTS chemical and physical properties and on plant growth. Specifically, the effect of storage on PTS pH, EC, CEC, C:N, particle size distribution, and BD was studied. The influence of PTS storage time on marigold growth was also studied.

\section{Materials and Methods}

Preparation of substrates. Fifteen-yearold loblolly pine (Pinus taeda L.) trees growing in Blackstone, VA, were harvested and delimbed on 16 Apr. 2009 and chipped on 21 Apr. 2009 with a Bandit chipper (Model 200; Bandit Industries, Inc., Remus, MI). These coarse pine chips were then passed through a hammermill (Meadow Mills, Inc., North Wilkesboro, NC) on 23 and 24 Apr. using a $4.76-\mathrm{mm}$ and a $15.9-\mathrm{mm}$ screen size. The PTS produced with the $4.76-\mathrm{mm}$ screen was used to produce a $100 \%$ PTS, and the coarser PTS (15.9-mm screen) was amended with peat (Premier Tech, Quebec, Canada; 3 PTS:1 peat, v:v). Previous work (Jackson et al., 2008a, 2010) has shown that these screen sizes produce a PTS and a PTSP with container capacity and total air space values within or near the recommended range of $45 \%$ to $65 \%$ for container capacity and $10 \%$ to $30 \%$ for total air space (Yeager et al., 2007). A PL substrate (4:1, v:v), similar to a conventional substrate for greenhousegrown crops, was included as a control. Both PTS and PTSP were amended with pulverized dolomitic limestone (Pro pulverized limestone; Old Castle Stone Products, Atlanta, GA; calcium carbonate equivalency of $95 \%$ ) at the rates of $0,1,2,4$, or $6 \mathrm{~kg} \cdot \mathrm{m}^{-3}$ for a total of 10 treatments; PL was amended with $6 \mathrm{~kg} \cdot \mathrm{m}^{-3}$ pulverized dolomitic limestone. Lime rates were chosen to accommodate a wide range of $\mathrm{pH}$ change possibilities over the $365-\mathrm{d}$ study period with $6 \mathrm{~kg} \cdot \mathrm{m}^{-3}$, the rate used commonly in the very acidic peat, as the highest rate. All 11 substrate treatments were amended with $0.6 \mathrm{~kg} \cdot \mathrm{m}^{-3}$ calcium sulfate $\left(\mathrm{CaSO}_{4}\right.$; Espoma Organic Traditions,

Table 1. Monthly high, low, and average daily temperatures at the Urban Horticulture Center in Blacksburg, VA, where substrates were stored in plastic storage bags on shelves in an open shed.

\begin{tabular}{lccc}
\hline & High $\left({ }^{\circ} \mathrm{C}\right)$ & Low $\left({ }^{\circ} \mathrm{C}\right)$ & $\begin{array}{c}\text { Avg daily } \\
\left({ }^{\circ} \mathrm{C}\right)\end{array}$ \\
\hline Apr. 2009 & 30 & -1 & 18 \\
May 2009 & 27 & 1 & 16 \\
June 2009 & 30 & 9 & 21 \\
July 2009 & 29 & 10 & 20 \\
Aug. 2009 & 30 & 14 & 21 \\
Sept. 2009 & 29 & 7 & 18 \\
Oct. 2009 & 29 & -3 & 11 \\
Nov. 2009 & 23 & -3 & 8 \\
Dec. 2009 & 15 & -12 & 1 \\
Jan. 2010 & 12 & -13 & -2 \\
Feb. 2010 & 7 & -8 & -2 \\
Mar. 2010 & 22 & -6 & 6 \\
\hline
\end{tabular}

Millville, NJ). Calcium sulfate has been shown to improve growth of herbaceous species in PTS (Saunders et al., 2005). After preparation, each substrate was placed in $85-\mathrm{L}$ perforated plastic bags and stored on shelves in an open shed in Blacksburg, VA, for $365 \mathrm{~d}$. Monthly high and low temperatures and average daily temperatures were monitored (Table 1).

Subsampling. At 1, 42, 84, 168, 270, and $365 \mathrm{~d}$ of storage, substrate subsamples from each treatment were transferred to twelve 1-L plastic containers. Six containers were left fallow and six were each planted with one 14-d-old marigold (Tagetes erecta L. 'Inca Gold') seedling; seedlings were grown in a 144-cell plug tray using Fafard Superfine Germinating Mix (Conrad Fafard, Inc., Agawam, MA). At Day $1, \approx 4 \mathrm{~L}$ each of PTS, PTSP, and PL without lime and gypsum amendments were placed in plastic freezer bags and stored in a freezer at $-15{ }^{\circ} \mathrm{C}$ for future $\mathrm{CEC}, \mathrm{C}, \mathrm{N}, \mathrm{BD}$, and particle size distribution analysis. For the remaining storage periods, $\approx 4 \mathrm{~L}$ of each of the 11 treatments was collected for the same analyses as at Day 1 and frozen as described previously.

Fallow containers. Fallow substrate-filled containers were arranged in a completely randomized design on a greenhouse bench with average day and night temperatures of 24 and $19{ }^{\circ} \mathrm{C}$, respectively. Each container was irrigated (beaker-applied) with $500 \mathrm{~mL}$ tap water to ensure thorough wetting, and the next day, substrate solution was extracted (six containers per treatment) using the pourthrough method (Wright, 1986). Substrate solution $\mathrm{pH}$ and EC were measured using a Hanna HI 9811 instrument (Hanna Instruments, Woonsocket, RI).

Containers with marigolds. Substratefilled containers with marigolds were arranged in a completely randomized design on a bench adjacent to the fallow containers. Each container was irrigated (beaker-applied) with $500 \mathrm{~mL}$ of a $300 \mathrm{mg} \cdot \mathrm{L}^{-1} \mathrm{~N}(8 \%$ ammonium, $12 \%$ nitrate), $20 \mathrm{~N}-4.4 \mathrm{P}-16.6 \mathrm{~K}$, complete fertilizer solution (Jack's Professional, Allentown, PA). The next day $250 \mathrm{~mL}$ of fertilizer solution was applied, which resulted in an $\approx 20 \%$ leaching fraction. Until the time of harvest ( 3 weeks), all containers received $250 \mathrm{~mL}$ fertilizer solution based on plant need for irrigation; when substrate solution EC values (measured weekly) were $2 \mathrm{dS} \cdot \mathrm{m}^{-1}$ or greater, tap water was used to irrigate all containers. After 3 weeks, substrate solutions were extracted using the pour-through technique (six containers per treatment) and analyzed for $\mathrm{pH}$ and $\mathrm{EC}$ as described previously. Growth index (GI) was determined by dividing the sum of marigold height, greatest width, and perpendicular width values by 3 . Marigold dry weight (DW) was determined by cutting the stems at substrate surface, drying in an oven at $65^{\circ} \mathrm{C}$ for $4 \mathrm{~d}$, and weighing. At Day 270 (Jan. 2010), plants were provided supplemental lighting using 400-W metal halide lamps from $0600 \mathrm{HR}$ to $2000 \mathrm{HR}$ daily.

Cation exchange capacity, carbon-tonitrogen ratio, particle size distribution, and bulk density. Cation exchange capacity,
$\mathrm{C}: \mathrm{N}$ ratio, particle size distribution, and $\mathrm{BD}$ were determined for five treatments: nonlimed PTS, non-limed PTSP, limed PTS $\left(1 \mathrm{~kg} \cdot \mathrm{m}^{-3}\right)$, limed PTSP $\left(4 \mathrm{~kg} \cdot \mathrm{m}^{-3}\right)$, and the PL control. These analyses were conducted on non-limed substrates stored for 1, 168, and $365 \mathrm{~d}$ and limed substrates stored for 168 and $365 \mathrm{~d}$. Because we assumed that the initial or Day 1 values would be the same for nonlimed and limed substrates, no analyses were conducted on the limed substrates at Day 1. The 1 - and $4-\mathrm{kg} \cdot \mathrm{m}^{-3}$ lime rates were chosen because the substrate solution $\mathrm{pH}$ values of these lime treatments were maintained in the 5.4 to 6.5 range, the recommended range for soilless greenhouse crops (Nelson, 2003). These analyses were conducted on the previously mentioned frozen subsamples with three replicates per treatment. Substrates were analyzed for CEC (A \& L Eastern Laboratories, Richmond, VA) using the Association of Official Analytical Chemists method 973.09 for peat materials (Thorpe, 1973). Values for CEC were measured in meq/100 $\mathrm{g}$ substrate and converted to $\mathrm{cmol} \cdot \mathrm{L}^{-1}$ substrate using BD values $\left(\mathrm{g} \cdot \mathrm{cc}^{-1}\right)$. For $\mathrm{C}: \mathrm{N}$ ratios, removal of any residual lime was necessary to obtain accurate $\mathrm{C}$ values in the limed treatments; thus, a modified acid fumigation method of Harris et al. (2001) was used. Acid-treated as well as non-acid treated samples were analyzed for C and N (Univ. of Florida Soil and Water Science Department Wetland Biogeochemistry Laboratory using a Thermo Electron Flash EA 1112 Nitrogen/Carbon Analyzer with MAS $200 \mathrm{R}$ autosampler; three replicates). Substrate BD was determined using the North Carolina State University Porometer Method (Fonteno and Hardin, 2003) for each of the five selected treatments with three replicates per treatment. For particle size distribution, $\approx 40 \mathrm{~g}$ oven-dried substrate was shaken for $10 \mathrm{~min}$ on a Fisher-Wheeler Sieve Shaker, Model \#5 (700 vibrations per minute) with 14 sieves ranging in size from greater than $6.3 \mathrm{~mm}$ to $0.63 \mathrm{~mm}$ and a bottom collection pan. Weights of each particle size fraction were recorded including the fraction in the pan. For ease and clarity of presentation, particle size textural classes of coarse, medium, and fine are presented here. Coarse, medium, and fine particles are segregated into $2 \mathrm{~mm}$ or greater in diameter, less than $2 \mathrm{~mm}$ but $0.5 \mathrm{~mm}$ or greater in diameter, and less than $0.5 \mathrm{~mm}$ in diameter, respectively.

Statistical analyses. Regression analysis (JMP 8; SAS Institute, Cary, NC) was used to describe data within substrates; analysis of variance with Tukey's honestly significant difference means comparison was used to separate treatment means between and within substrates (JMP 8; SAS Institute).

\section{Results and Discussion}

Substrate solution $\mathrm{pH}$ (fallow containers). On Day 1, pH values of all treatments, with the exception of non-limed PTSP ( $\mathrm{pH}$ value of 5.2), were within or slightly above the generally accepted range (5.4 to 6.5; Nelson, 2003) for non-ericaceous crops (Table 2). 
Table 2. Pine tree substrate (PTS), PTS:peat substrate (3:1, v:v, PTSP), and peat:perlite substrate (4:1, v:v, PL) solution extract pH values and electrical conductivity (EC) levels at varying lime rates after $1,42,84,168,270$, and $365 \mathrm{~d}$ of storage $(\mathrm{n}=6)$.

\begin{tabular}{|c|c|c|c|c|c|c|c|c|c|c|c|c|}
\hline \multirow{2}{*}{$\frac{\text { Substrate }}{\text { Lime rate }\left(\mathrm{kg} \cdot \mathrm{m}^{-3}\right)}$} & \multicolumn{2}{|r|}{ Day 1} & \multicolumn{2}{|r|}{ Day 42} & \multicolumn{2}{|r|}{ Day 84} & \multicolumn{2}{|c|}{ Day 168} & \multicolumn{2}{|c|}{ Day 270} & \multicolumn{2}{|c|}{ Day 365} \\
\hline & $\mathrm{pH}$ & $\overline{E C}\left(\mathrm{dS} \cdot \mathrm{m}^{-1}\right)$ & $\mathrm{pH}$ & $\overline{E C}\left(\mathrm{dS} \cdot \mathrm{m}^{-1}\right)$ & $\mathrm{pH}$ & $\overline{E C}\left(\mathrm{dS} \cdot \mathrm{m}^{-1}\right)$ & $\mathrm{pH}$ & $\overline{E C}\left(\mathrm{dS} \cdot \mathrm{m}^{-1}\right)$ & $\mathrm{pH}$ & $\overline{E C}\left(\mathrm{dS} \cdot \mathrm{m}^{-1}\right)$ & $\mathrm{pH}$ & $\mathrm{EC}\left(\mathrm{dS} \cdot \mathrm{m}^{-1}\right)$ \\
\hline 0 & $5.8 \mathrm{e}^{\mathrm{z}}$ & $1.10 \mathrm{bc}$ & $5.2 \mathrm{~g}$ & $0.55 \mathrm{de}$ & $5.3 \mathrm{e}$ & $0.69 \mathrm{~d}$ & $5.2 \mathrm{f}$ & $0.73 a b c$ & $5.0 \mathrm{~g}$ & $0.73 \mathrm{ab}$ & $5.0 \mathrm{~g}$ & $0.75 \mathrm{ab}$ \\
\hline 4 & $6.5 \mathrm{ab}$ & $1.15 \mathrm{ab}$ & $6.3 \mathrm{~b}$ & $0.58 \mathrm{de}$ & $6.8 \mathrm{~b}$ & $0.82 \mathrm{bc}$ & $6.8 \mathrm{a}$ & $0.72 a b c$ & $6.8 \mathrm{~b}$ & $0.74 \mathrm{ab}$ & $6.7 \mathrm{a}$ & $0.62 \mathrm{c}$ \\
\hline 6 & $6.6 \mathrm{a}$ & $1.21 \mathrm{a}$ & $6.5 \mathrm{a}$ & $0.58 \mathrm{de}$ & $7.0 \mathrm{a}$ & $0.81 \mathrm{bc}$ & $6.9 \mathrm{a}$ & $0.70 \mathrm{c}$ & $7.0 \mathrm{a}$ & $0.69 \mathrm{ab}$ & $6.8 \mathrm{a}$ & $0.71 \mathrm{abc}$ \\
\hline Significance $\mathrm{y}$ & $\mathrm{Q}^{* * *}$ & $\mathrm{Q}^{*}$ & $\mathrm{Q}^{* * *}$ & NS & $\mathrm{Q}^{* * *}$ & $\mathrm{Q} * * *$ & $\mathrm{Q}^{* * *}$ & NS & $\mathrm{Q}^{* * *}$ & NS & $\mathrm{Q}^{* * *}$ & $\mathrm{Q} * *$ \\
\hline \multicolumn{13}{|l|}{ PTSP } \\
\hline 0 & $5.2 \mathrm{f}$ & $1.09 \mathrm{bc}$ & $4.3 \mathrm{i}$ & $0.71 \mathrm{~b}$ & $4.4 \mathrm{~g}$ & $0.80 \mathrm{bcd}$ & $4.4 \mathrm{~h}$ & $0.74 a b c$ & $4.1 \mathrm{i}$ & $0.70 \mathrm{ab}$ & $4.1 \mathrm{i}$ & $0.64 b c$ \\
\hline 1 & $5.7 \mathrm{e}$ & $1.15 \mathrm{ab}$ & $5.0 \mathrm{~h}$ & $0.70 \mathrm{bc}$ & $5.1 \mathrm{f}$ & $0.76 \mathrm{bcd}$ & $5.1 \mathrm{~g}$ & $0.70 \mathrm{c}$ & $4.8 \mathrm{~h}$ & $0.72 \mathrm{ab}$ & $4.7 \mathrm{~h}$ & $0.65 \mathrm{bc}$ \\
\hline 2 & $6.1 \mathrm{~d}$ & $1.13 \mathrm{ab}$ & $5.4 \mathrm{f}$ & $0.71 \mathrm{~b}$ & $5.7 \mathrm{~d}$ & $0.78 \mathrm{~cd}$ & $5.7 \mathrm{e}$ & $0.72 b c$ & $5.5 \mathrm{f}$ & $0.69 \mathrm{ab}$ & $5.4 \mathrm{f}$ & $0.64 b c$ \\
\hline 4 & $6.4 \mathrm{ab}$ & $1.02 \mathrm{c}$ & $6.1 \mathrm{c}$ & $0.82 \mathrm{a}$ & $6.4 \mathrm{c}$ & $0.81 \mathrm{bc}$ & $6.4 \mathrm{~d}$ & $0.82 \mathrm{a}$ & $6.2 \mathrm{e}$ & $0.80 \mathrm{a}$ & $6.1 \mathrm{e}$ & $0.70 a b c$ \\
\hline 6 & $6.6 \mathrm{a}$ & $1.14 \mathrm{ab}$ & $6.4 \mathrm{a}$ & $0.86 \mathrm{a}$ & $6.8 \mathrm{~b}$ & $0.86 \mathrm{~b}$ & $6.7 \mathrm{~b}$ & $0.79 a b c$ & $6.6 \mathrm{c}$ & $0.80 \mathrm{a}$ & $6.4 \mathrm{c}$ & $0.80 \mathrm{a}$ \\
\hline Significance & $\mathrm{Q}^{* * *}$ & NS & $\mathrm{Q}^{* * *}$ & $\mathrm{~L}^{* * *}$ & $\mathrm{Q}^{* * *}$ & $\mathrm{Q}^{* *}$ & $\mathrm{Q}^{* * *}$ & $\mathrm{~L}^{* *}$ & $\mathrm{Q}^{* * *}$ & $\mathrm{~L}^{* * *}$ & $\mathrm{Q}^{* * *}$ & $\mathrm{Q}^{* * *}$ \\
\hline
\end{tabular}

PL

$\begin{array}{lllllllll}6 & 6.5 \mathrm{a} & 1.15 \mathrm{ab} & 6.2 \mathrm{bc} & 0.87 \mathrm{a} & 6.5 \mathrm{c} & 1.02 \mathrm{a} & 6.4 \mathrm{~d} & 0.81 \mathrm{ab}\end{array}$

$6.4 \mathrm{~d} \quad 0.74 \mathrm{ab}$

$6.4 \mathrm{c} \quad 0.71 \mathrm{abc}$

${ }^{\mathrm{z}}$ Means within columns across substrates separated by Tukey's honestly significant difference $(P \leq 0.05)$

$\mathrm{y}_{\mathrm{NS}}=$ Nonsignificant or significant at $* P \leq 0.05, * * 0.01$, or $* * * 0.001 ; \mathrm{L}=$ linear, $\mathrm{Q}=$ quadratic response for lime rate at $*, * *$, or $* * *$

Non-limed PTSP pH values were at least 0.6 units lower than non-limed PTS pH values throughout the study as a result of the acidifying effect of peat, an effect that has been observed by others (Jackson et al., 2009a; Wang, 1998; Wang and Konow, 2002). By Day 42, $\mathrm{pH}$ values of all treatments decreased and at least 1 and $2 \mathrm{~kg} \cdot \mathrm{m}^{-3}$ lime were needed to maintain PTS and PTSP $\mathrm{pH}$ values, respectively, at 5.4 and higher (Table 2). The $\mathrm{pH}$ for non-limed PTS decreased over time and was less than the lower recommended $\mathrm{pH}$ value for most greenhouse crops (5.4; Nelson, 2003) but suitable for ericaceous species (recommended $\mathrm{pH}$ values of 4.5 to 5.5; Yeager et al., 2007). For non-limed PTSP, $\mathrm{pH}$ was less than 4.5 for all sampling dates after Day 1. From Day 42 to Day 84 for limed PTS and limed PTSP treatments, $\mathrm{pH}$ increased (Table 2). Values remained relatively stable throughout the remainder of the experiment for all limed PTS treatments (Table 2). In contrast, $\mathrm{pH}$ values of PTSP limed treatments decreased from Day 84 (Table 2). In the 2-, 4-, and $6-\mathrm{kg} \cdot \mathrm{m}^{-3}$ lime rates of PTS, and the $6-\mathrm{kg} \cdot \mathrm{m}^{-3}$ lime rate of PTSP, $\mathrm{pH}$ values were higher than the suggested upper recommended limit (6.5; Nelson, 2003) at 1 or more subsampling days. Like with PTS and PTSP, PL pH decreased from Day 1 to Day 42 (6.5 to 6.2) and stabilized at 6.4 to 6.5 thereafter (Table 2). The $\mathrm{pH}$ of PL (limed with $6.0 \mathrm{~kg} \cdot \mathrm{m}^{-3}$ ) was generally lower than PTS and PTSP $\mathrm{pH}$ limed at 4 and $6 \mathrm{~kg} \cdot \mathrm{m}^{-3}$ and was similar to $\mathrm{pH}$ values of PTS limed at 1 and $2 \mathrm{~kg} \cdot \mathrm{m}^{-3}$ and PTSP limed at $4 \mathrm{~kg} \cdot \mathrm{m}^{-3}$. Thus, less lime is required to adjust PTS and PTSP $\mathrm{pH}$ compared with lime additions for PL.

Substrate solution electrical conductivity (fallow containers). Day $1 \mathrm{EC}$ values were between 1.02 and $1.21 \mathrm{dS} \cdot \mathrm{m}^{-1}$ for all substrate and lime treatments (Table 2). By Day 42, EC values decreased by $50 \%$ in PTS, $20 \%$ to $40 \%$ in PTSP, and $25 \%$ in PL. The decrease in substrate solution salt indicates salt uptake, most likely by microorganisms present in the substrate during the first $42 \mathrm{~d}$ of storage. Salts in wood, the most abundant of which are calcium, potassium, and magnesium, contributing to EC, are mainly from deposits in cell walls and lumina (Sjöström, 1993). Although peat is considered stable, the addition of lime to this substrate at the initiation of storage may have activated microorganisms present in peat (Carlile and Wilson, 1991), and the subsequent microbial proliferation could result in microbial immobilization of solution salts. The salt contribution from irrigation water was minor because irrigation water $\mathrm{EC}$ value was $0.1 \mathrm{dS} \cdot \mathrm{m}^{-1}$. The EC contribution from lime was also low because non-limed substrate EC values were similar to limed substrates. After Day 42, EC values were approximately the same or higher throughout the rest of the experiment, but never as high as Day 1 values.

Cation exchange capacity. Cation exchange capacity values decreased linearly over the $365-\mathrm{d}$ period from 2.0 to $1.7 \mathrm{cmol} \cdot \mathrm{L}^{-1}$ for non-limed PTS and from 5.7 to $4.6 \mathrm{cmol} \cdot \mathrm{L}^{-1}$ for non-limed PTSP (Table 3). Values for limed PTS increased from Day 1 to Day 168; the Day 365 value was the same as the Day 168 value. Values for limed PTSP decreased from Day 1 to Day 168, but the Day 365 value was the same as the Day 1 value. Cation exchange capacity would not play a significant role in supplying plants with nutrients as a result of the relatively high nutrient amounts of commercial fertilizer regimes, and so these relatively small changes would be inconsequential in conventionally fertilized plant production systems. The addition of peat to PTS (PTSP substrate) nearly tripled the CEC of PTS (Table 3). There was no change in PL CEC over the 365-d storage period (Table 3 ), but values were six times
Table 3. Cation exchange capacity (CEC) of nonlimed and limed pine tree substrate (PTS), PTS:peat substrate (3:1, v:v, PTSP), and peat:perlite substrate $(4: 1, \mathrm{v}: \mathrm{v}, \mathrm{PL})$ after 1 , 168 , and $365 \mathrm{~d}$ of storage $(\mathrm{n}=3)$.

\begin{tabular}{lllll}
\hline $\begin{array}{c}\text { Substrate } \\
\text { Lime rate }\end{array}$ & \multicolumn{4}{c}{ CEC $\left(\mathrm{cmol} \cdot \mathrm{L}^{-1}\right)$} \\
\cline { 3 - 6 }$\left(\mathrm{kg} \cdot \mathrm{m}^{-3}\right)$ & Day 1 & $\begin{array}{c}\text { Day } \\
168\end{array}$ & $\begin{array}{l}\text { Day } \\
365\end{array}$ & Significance \\
\hline PTS & & & & \\
0 & 2.0 & $1.9 \mathrm{~b}^{\mathrm{y}}$ & $1.7 \mathrm{~b}$ & $\mathrm{~L}^{* * *}, r^{2}=0.90$ \\
1 & 2.0 & $2.5 \mathrm{a}$ & $2.5 \mathrm{a}$ & $\mathrm{Q}^{*}, r^{2}=0.80$ \\
& & & & \\
PTSP & & & & \\
0 & 5.7 & $5.4 \mathrm{a}$ & $4.6 \mathrm{a}$ & $\mathrm{L}^{*}, r^{2}=0.93$ \\
4 & 5.7 & $5.3 \mathrm{a}$ & $5.7 \mathrm{a}$ & $\mathrm{Q}^{* *}, r^{2}=0.82$
\end{tabular}

PL

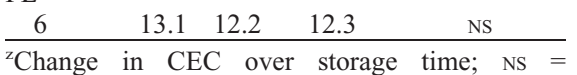
nonsignificant or significant at $* P \leq 0.05$, $* * 0.01$, or $* * * 0.001 ; \mathrm{L}=$ linear, $\mathrm{Q}=$ quadratic response for storage time at $*, * *$, or $* * *$.

${ }^{y}$ Means separated within columns (between lime rates within each substrate).

that of PTS and approximately two times that of PTSP, showing one of the advantages of a peat-based substrate over a PTS substrate and one reason why more fertilizer is required for PTS compared with a PL mix (Jackson et al., 2009b).

Carbon-to-nitrogen ratio. The $\mathrm{C}: \mathrm{N}$ ratios over time for PTS without lime ranged from 177 to 179 (sampling at Days 1, 168, and 365) and from 155 to 179 for the $1-\mathrm{kg} \cdot \mathrm{m}^{-3}$ lime treatment (Table 4). Ratios were the same for limed and non-limed PTS at sampling Days 1,168 , and 365 and at each of these sampling dates. The day $1 \mathrm{C}: \mathrm{N}$ ratio of non-limed PTS was 179:1, a much lower value than the value reported by Jackson et al. (2008b) for nonlimed PTS. Carbon-to-nitrogen ratios for PTSP with and without lime ranged from 88:1 to $92: 1$. Similar to PTS, the PTSP C:N 
Table 4. Carbon-to-nitrogen ratio (C:N) of nonlimed and limed pine tree substrate (PTS), PTS:peat substrate (3:1, v:v, PTSP), and peat: perlite (4:1, v:v, PL) after 1, 168, and $365 \mathrm{~d}$ of storage $(n=3)$.

\begin{tabular}{|c|c|c|c|c|}
\hline \multirow{2}{*}{$\frac{\text { Substrate }}{\text { Lime rate }}$} & \multicolumn{4}{|c|}{ C:N } \\
\hline & Day 1 & $\begin{array}{l}\text { Day } \\
168 \\
\end{array}$ & $\begin{array}{l}\text { Day } \\
365\end{array}$ & Significance \\
\hline \multicolumn{5}{|l|}{ PTS } \\
\hline 0 & 179 & $178 a^{z}$ & $177 \mathrm{a}$ & NS \\
\hline 1 & 179 & $155 \mathrm{a}$ & $169 \mathrm{a}$ & NS \\
\hline \multicolumn{5}{|l|}{ PTSP } \\
\hline 0 & 90 & $91 \mathrm{a}$ & $92 \mathrm{a}$ & NS \\
\hline 4 & 90 & $88 \mathrm{a}$ & $90 \mathrm{a}$ & NS \\
\hline
\end{tabular}

PL

\begin{tabular}{ccccc}
6 & 53 & 51 & 54 & NS \\
\hline${ }^{2}$ Means separated within columns & (between lime
\end{tabular} rates within each substrate) by Tukey's honestly significant difference $(P \leq 0.05)$.

${ }^{\mathrm{y}}$ Change in $\mathrm{C}: \mathrm{N}$ over storage time; $\mathrm{NS}=$ nonsignificant at $P \leq 0.05$.

ratios for with and without lime treatments were the same over time and ratios were the same for lime and without lime at Days 1, 168, and 365 (Table 4). Amending PTS with peat ( $25 \%$ by vol.) decreased the $\mathrm{C}: \mathrm{N}$ ratio by $50 \%$. The C:N ratio for PL ranged from 51:1 to $54: 1$ over time and was unaffected by storage time. Because the PL C:N ratio ( $\approx 53: 1)$ is considerably lower than the PTS ratio, the PTSP C:N ratio was expectedly lower than PTS. The PL C:N ratio found in this study is consistent with other reported peat $\mathrm{C}: \mathrm{N}$ values (Marrush, 2007; Tripepi, 2008). Beof lime rate, were the same over time, we infer that there was no appreciable decomposition of PTS and PTSP during $365 \mathrm{~d}$ of storage. Although this demonstrates substrate stability, the maintenance of a relatively high ratio over time will result in $\mathrm{N}$ immobilization when these stored substrates are used, and higher than conventional $\mathrm{N}$ application rates will be required for crop production. Jackson et al. (2009b) showed that N immobilization is substantially greater in PTS than in PL. These authors have also shown that plants grown in PTS and PTSP required more $\mathrm{N}$ than plants grown in PL (Wright et al., 2008).

In the $\mathrm{C}: \mathrm{N}$ determination methodology, limed PTS samples were treated with acid or without acid to measure the contribution of the $\mathrm{C}$ in the lime amendment to the ratio. Acidification of samples would convert the $\mathrm{C}$ associated with the lime to a gas and therefore would not be measured in the $\mathrm{C}: \mathrm{N}$ analysis. The C:N ratios for limed PTS of acid-treated and non-acid-treated samples were the same at Day 168 and Day 365 (data not shown). The same result was also true for limed PTSP. The calculated amount of $\mathrm{C}$ contributed by $1 \mathrm{~kg} \cdot \mathrm{m}^{-3}$ lime to PTS was $1.1 \mathrm{~g} \cdot \mathrm{kg}^{-1}$ of substrate, a relatively insignificant contribution to the $\mathrm{C}: \mathrm{N}$ ratio. The amount of $\mathrm{C}$ contributed by $4 \mathrm{~kg} \cdot \mathrm{m}^{-3}$ lime to PTSP would be $4.3 \mathrm{~g} \cdot \mathrm{kg}^{-1}$. Although there were no differences between non-acidified and acidified $\mathrm{C}: \mathrm{N}$ ratios for the $4-\mathrm{kg} \cdot \mathrm{m}^{-3}$ lime rate cause $\mathrm{C}: \mathrm{N}$ ratios in all substrates, regardless

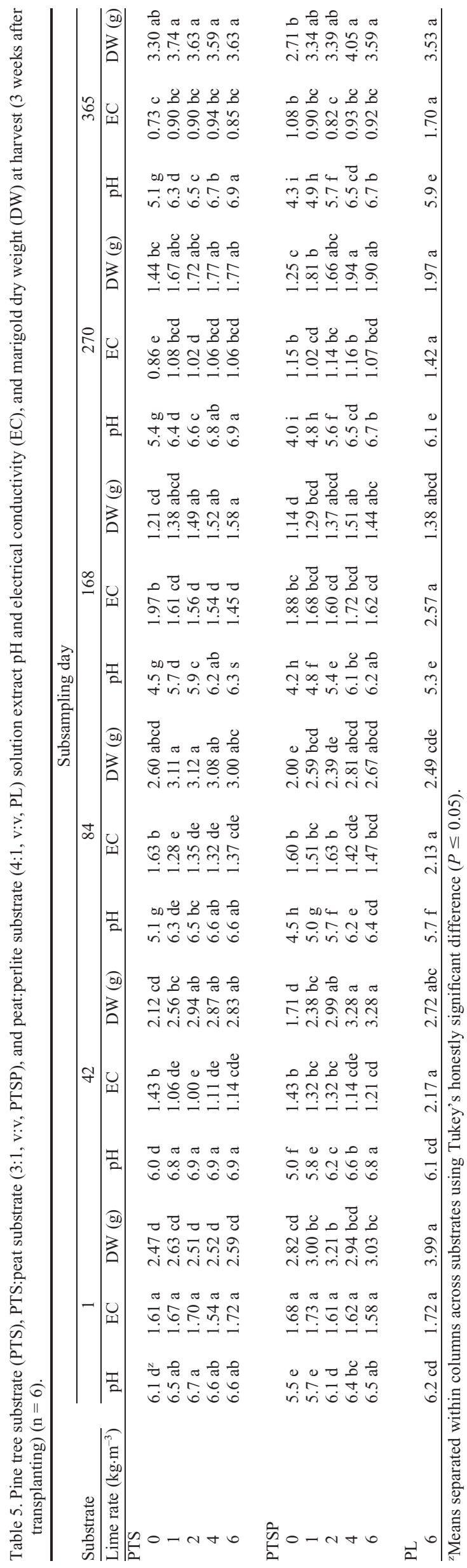

HortScience Vol. 47(12) December 2012 


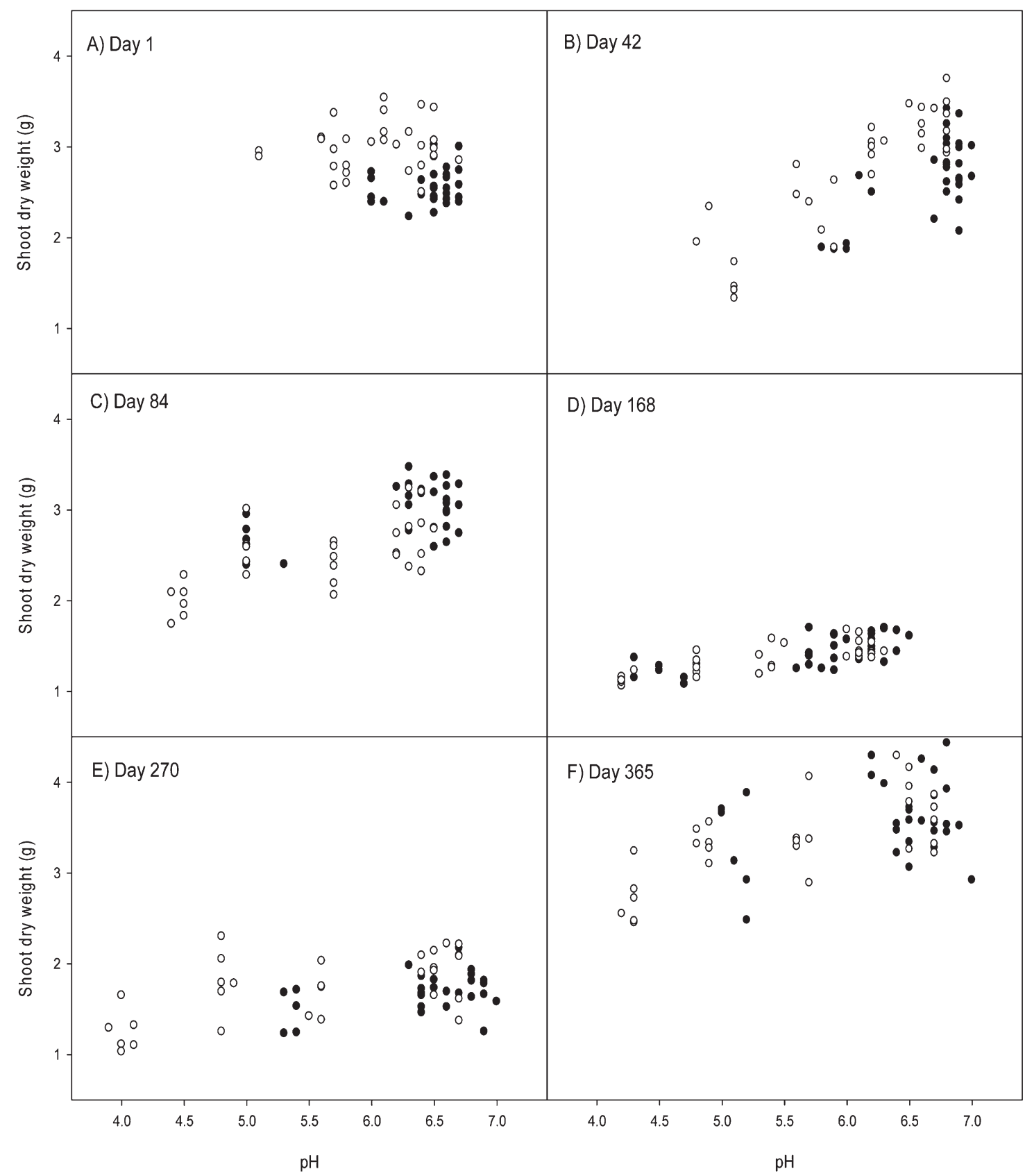

Fig. 1. Marigold dry weight by substrate solution $\mathrm{pH}$ at six subsampling days from Apr. 2009 to Apr. 2010 for pine tree substrate (@, PTS) and PTS:peat (3:1, v:v) substrate $(\mathrm{O}, \mathrm{PTSP})$. (A) Day 1 (no significant differences for PTS or PTSP); (B) Day 42 (PTS: $\mathrm{y}=-2.6624+0.7970 \mathrm{x}, r^{2}=0.44, P<0.0001$ and PTSP: $\left.\mathrm{y}=-2.7281+0.8974 \mathrm{x}, r^{2}=0.76, P<0.0001\right) ;\left(\right.$ C) Day 84 (PTS: $\mathrm{y}=1.2056+0.2862 \mathrm{x}, r^{2}=0.32, P=0.0011$ and PTSP: $\mathrm{y}=0.7305+0.3170 \mathrm{x}, r^{2}=0.40$, $P=0.0002$ ); (D) Day 168 (PTS: $\mathrm{y}=0.3616+0.1873 \mathrm{x}, r^{2}=0.46, P<0.0001$ and PTSP: $\mathrm{y}=0.4567+0.1672 \mathrm{x}, r^{2}=0.59, P<0.0001$ ); (E) Day 270 (PTS: $\mathrm{y}=0.3873+0.2016 \mathrm{x}, r^{2}=0.23, P=0.0092$ and PTSP: $\left.\mathrm{y}=0.5465+0.2124 \mathrm{x}, r^{2}=0.34, P=0.0010\right) ;($ F) Day 365 (PTS: no significant differences and PTSP: $\left.\mathrm{y}=1.1625+0.4029 \mathrm{x}, r^{2}=0.48, P<0.0001\right)$.

PTSP, total C values of non-acidified samples were 6 and $11 \mathrm{~g} \cdot \mathrm{kg}^{-1}$ higher than acidified samples for Day 168 and Day 365, respectively (data not shown). Acid fumigation of samples for $\mathrm{C}: \mathrm{N}$ determinations of substrates seems warranted with this rate of lime addition. Regardless of lime amendment rate, acid fumigation would dissolve lime aggregates present in the substrate and result in a more accurate value than without acid fumigation.

Particle size analysis. Particle size fractions for non-limed and limed $\left(1 \mathrm{~kg} \cdot \mathrm{m}^{-3}\right.$ treatment) PTS were unaffected over the $365-\mathrm{d}$ storage period with the exception of an increase over time (from $72 \%$ to $78 \%$ ) in medium-sized particles of the limed treatment. The reason for this change is unclear. For non-limed PTS, the medium particle size fraction was constant at $\approx 71 \%$. For both nonlimed and limed PTS, the coarse particle size fraction was $\approx 4 \%$ and the fine particle size fraction was $25 \%$ and $22 \%$ for PTS nonlimed and PTS limed, respectively. It is the fine particle texture group that has a major influence on the physical characteristics of potting substrate, e.g., air space, container capacity, and ease of water release (Handreck,
1983). Pine tree substrate, therefore, appears to be relatively stable physically over the course of one year.

Bulk density. Bulk densities remained relatively unchanged over $365 \mathrm{~d}$ of storage for all substrates (data not shown). Bulk density values for PTS, non-limed and limed, and $\mathrm{PL}$ were $\approx 0.11 \mathrm{~g} \cdot \mathrm{cc}^{-1}$, whereas values for PTSP, non-limed and limed, were $0.12 \mathrm{~g} \cdot \mathrm{cc}^{-1}$. Unchanging BD values further indicate the physical stability of PTS.

Marigold growth. Shoot DW for PL (limed at $6 \mathrm{~kg} \cdot \mathrm{m}^{-3}$ ) at $1 \mathrm{~d}$ of storage was higher than DW for PTS and PTSP regardless 
of lime rate (Table 5). After Day 1, DW for PTS and PTSP was the same as or higher than DW for PL. Exceptions are non-limed PTS at Day 270 in which the $\mathrm{pH}$ was 5.4; non-limed PTSP on Days 42, 270, and 365 in which the $\mathrm{pH}$ values were 5.0, 4.0, and 4.3, respectively; and PTSP limed at $1 \mathrm{~kg} \cdot \mathrm{m}^{-3}$ on Day 270 in which the $\mathrm{pH}$ value was 4.8 ; values less than 6.0 are considered undesirable for marigold growth (Whipker et al., 2000). There was no relationship between marigold shoot DW and substrate solution $\mathrm{pH}$ for PTS or PTSP stored for $1 \mathrm{~d}$ (Fig. 1A). The $\mathrm{pH}$ values for PTS ranged from 6.1 to 6.7 (Table 5) within or near the recommended 6.0 to 6.6 range recommended for marigold culture (Whipker et al., 2000), whereas $\mathrm{pH}$ values for PTSP ranged from 5.5 to 6.5 (Table 5). By Day 42, there was a positive relationship between DW and $\mathrm{pH}$ for both PTS and PTSP (Fig. 1B). Day $42 \mathrm{PTS} \mathrm{pH}$ values ranged from 6.0 to 6.9 , whereas PTSP $\mathrm{pH}$ values ranged from 5.0 to 6.8 (Table 5). Positive relationships between $\mathrm{DW}$ and $\mathrm{pH}$ were also found for both PTS and PTSP for the duration of the storage period (Fig. 1C-F) except for PTS at Day 365. For PTS, minimum $\mathrm{pH}$ values for these last four sub-sampling days ranged from 4.5 to 5.4 , whereas maximum $\mathrm{pH}$ values ranged from 6.3 to 6.9 (Table 5). For PTSP, minimum $\mathrm{pH}$ values ranged from 4.0 to 4.5 , whereas maximum $\mathrm{pH}$ values ranged from 6.2 to 6.7 (Table 5). Comparison of PTS and PTSP coefficients of determination $\left(r^{2}\right.$ values; Fig. 1B-F) consistently showed a closer relationship between marigold $\mathrm{DW}$ and $\mathrm{pH}$ in PTSP than in PTS. Low $r^{2}$ values for PTS indicate that other factor(s) influenced marigold DW. Absence or presence of relationships between GI and $\mathrm{pH}$ for PTS and PTSP were the same as those of DW and $\mathrm{pH}$ (data not shown). Differences in $\mathrm{pH}$ resulting from substrate and lime rate were consistent with $\mathrm{pH}$ levels found with fallow containers at each sampling date (Table 2). The lower marigold DW values in PTS compared with PL at Day 1, when $\mathrm{pH}$ for PTS was within an acceptable range, suggests that there may be some inhibitory substance(s) or phytotoxin(s) at Day 1 in PTS that is no longer present or present in a relatively low concentration by Day 42 . Phytotoxic compounds are wood extractives, extractives defined as the nonstructural constituents of wood that are soluble in neutral organic solvents or water (Sjöström, 1993). This possibility of phytotoxic compounds in PTS inhibiting plant growth is supported by work of Gruda et al. (2009) who found that lettuce and tomato seed radical length values were lower when sown on germination paper saturated with hot or cold water extracts of PTS as compared with values when sown on germination paper soaked with distilled water. This study also showed that leaching PTS with cold or hot water and then conducting the radical length determination reduced the growth inhibitory influence compared with non-leached PTS. In this same study, marigold DW in a freshly manufactured non-limed PTS was less than in a PL control, but DW was the same as PL when the PTS was previously washed or leached.

Gaches et al. (2011) also speculated that some chemical is present in recently manufactured WholeTree substrate that inhibits plant growth. Jackson et al. (2009a) reported that marigold (Tagetes erecta L. 'Inca Gold') DW for PTS and PTSP was equal to or higher than that of PL, and the PTS and PTSP (3 PTS: 1 peat, v:v) used were manufactured 105 and $135 \mathrm{~d}$ before planting. Thus, this time lag from substrate manufacture to planting may have allowed the phytotoxic compounds in PTS to be degraded and may be the likely reason that the DW values of the aforementioned wood-based substrates of Jackson et al. were the same as DW values for PL. The release of these extractives from PTS may also explain the decrease in $\mathrm{pH}$ seen in all PTS and PTSP treatments by Day 42 (Table 2). Extractives are readily consumed by microorganisms and their degradation leads to production of organic acids and a decrease in $\mathrm{pH}$ (Crawford, 1983; Gray et al., 1971; Tuomela et al., 2000). Apparently the majority of these extractives were degraded by Day 42 , because $\mathrm{pH}$ values after this day decreased slowly compared with the Day 1 to Day 42 period. This would also be a possible explanation for the finding that marigold DW of PTS and PTSP at all lime rates, except non-limed PTSP, is similar to PL by Day 42. Complete degradation of phytotoxins may also help explain why there was no relationship between pH and DW in PTS at Day 365. We suggest that growers lime PTS and store the substrate for 6 weeks to avoid problems with phytotoxins of fresh PTS.

In conclusion, results of this work have shown that the $\mathrm{pH}$ of PTS and PTSP decreases during storage with the majority of the decrease occurring by 6 weeks of storage. The likely mechanism behind this initial decrease is the microbial degradation of easily accessible extractives resulting in production of organic acids. The addition of $1 \mathrm{~kg} \cdot \mathrm{m}^{-3}$ lime to PTS before storage maintained the $\mathrm{pH}$ of this substrate within recommended $\mathrm{pH}$ limits for soilless substrates, whereas at least 2 to $4 \mathrm{~kg} \cdot \mathrm{m}^{-3}$ lime addition was needed to maintain PTSP $\mathrm{pH}$ within recommended limits. Results of the marigold growth experiment support the hypothesis for the presence of phytotoxic extractives in freshly manufactured PTS. The results of these experiments were conducted on an annual plant species with a liquid fertilization regime; thus, results may not be extrapolated to woody perennial species or plants fertilized with controlledrelease fertilizers.

\section{Literature Cited}

Boyer, C. 2009. Production of woody nursery crops in clean chip residual substrate. J. Environ. Hort. 27:56-62.

Boyer, C.R., G.B. Fain, C.H. Gilliam, T.V. Gallagher, H.A. Torbert, and J.L. Sibley. 2008. Clean chip residual: A substrate component for growing annuals. HortTechnology 18:423-432.

Boyer, C.R., H.A. Torbert, C.H. Gilliam, G.B. Fain, T.V. Gallagher, and J.L. Sibley. 2012.
Nitrogen immobilization in plant growth substrates: Clean chip residual, pine bark, and peatmoss. Intl. J. Agron. <http://www.hindawi. com/journals/ija/2012/978528/>.

Carlile, W.R. and D.P. Wilson. 1991. Microbial activity in growing media-a brief review. Acta Hort. 294:197-206.

Crawford, J.H. 1983. Composting of agricultural wastes - A review. Process Biochem. 18:14-18.

Dickinson, K. and W.R. Carlile. 1995. The storage properties of wood-based peat-free growing media. Acta Hort. 401:89-96.

Fain, G.B., C.H. Gilliam, and J.L. Sibley. 2006. Processed whole pine trees as a substrate for container-grown plants. Proc. Southern Nursery Assn. Res. Conf. 51:59-61.

Fain, G., C.H. Gilliam, J.L. Sibley, and C.R. Boyer. 2008a. WholeTree substrates derived from three species of pine in production of annual vinca. HortTechnology 18:13-17.

Fain, G., C.H. Gilliam, J.L. Sibley, and C.R. Boyer. 2008b. WholeTree substrate and fertilizer rate in production of greenhouse-grown petunia (Petunia $\times$ hybrida Vilm.) and marigold (Tagetes patula L.). HortScience 43:700-705.

Fonteno, W.C. and C.T. Hardin. 2003. Procedures for determining physical properties of horticultural substrates using the NCSU porometer. Horticultural Substrates Laboratory, North Carolina State University, Raleigh, NC.

Gaches, W., G.B. Fain, D.J. Eakes, C.H. Gilliam, and J.F. Sibley. 2011. Comparison of aged and fresh WholeTree as a substrate component for production of greenhouse-grown annuals. J. Environ. Hort. 29:39-44.

Gray, K.R., K. Sherman, and A.J. Biddlestone. 1971. A review of composting-Part 1. Process Biochem. 6:32-36.

Gruda, N., B.J. Rau, and R.D. Wright. 2009. Laboratory bioassay and greenhouse evaluation of a pine tree substrate used as a container substrate. Eur. J. Hort. Sci. 74:73-78.

Gruda, N. and W.H. Schnitzler. 2004. Suitability of wood-fiber substrate for production of vegetable transplants. I. Physical properties of wood fiber substrates. Sci. Hort. 100:309-322.

Gruda, N., S.V. Tucher, and W.H. Schnitzler. 2000. $\mathrm{N}$-immobilization of wood fiber substrates in the production of tomato transplants [Lycopersicon lycopersicum (L.) Karst. ex Farw.]. J. Appl. Botany 74:32-37.

Gumy, N. 2001. Toresa and other wood-fiber products; advantages and drawbacks when used in growing media. Proc. Inter. Peat Symp. p. 39-46.

Handreck, K.A. 1983. Particle size and the physical properties of growing media for containers Commun. Soil Sci. Plant Anal. 14:209-222.

Harris, D., W.R. Horwath, and C. Van Kessel. 2001. Acid fumigation of soils to remove carbonates prior to total organic carbon or carbon13 isotopic analysis. Soil Sci. Amer. J. 65 $1853-1856$

Jackson, B.E., R.D. Wright, and M.C. Barnes. 2008a. Pine tree substrate, nitrogen rate, particle size, and peat amendment affect poinsettia growth and substrate physical properties. HortScience 43:2155-2161.

Jackson, B.E., R.D. Wright, J.F. Browder, J.R Harris, and A.X. Niemiera. 2008b. Effect of fertilizer rate on growth of azalea and holly in pine bark and pine tree substrates. HortScience 43:1561-1568

Jackson, B.E., R.D. Wright, and N. Gruda. 2009a. Container medium $\mathrm{pH}$ in a pine tree substrate amended with peatmoss and dolomitic limestone affects plant growth. HortScience 44:1983-1987. 
Jackson, B.E., R.D. Wright, and M.M. Alley. 2009b. Comparison of fertilizer nitrogen availability, nitrogen immobilization, substrate carbon dioxide efflux, and nutrient leaching in peat-lite, pine bark, and pine tree substrates. HortScience 44:781-790.

Jackson, B.E., R.D. Wright, and M.C. Barnes. 2010. Methods of constructing a pine tree substrate from various wood particle sizes, organic amendments, and sand for desired physical properties and plant growth. HortScience 45: 103-112.

Kostov, O., V. Rankov, G. Atanacova, and J.M. Lynch. 1991. Decomposition of sawdust and bark treated with cellulose-decomposing microorganisms. Biol. Fertil. Soils 11:105110 .

Marrush, M. 2007. Carbon:nitrogen ratio. University of California, Davis. 17 Sept. 2011. <http:// afghanag.ucdavis.edu/a_horticulture/.../FS_ Carbon Nitrogen.doc $>$.

Nelson, P.V. 2003. Greenhouse operations and management. $6^{\text {th }}$ Ed. Prentice Hall, Englewood Cliffs, NJ.
Saunders, T., R. Wright, and J.F. Browder. 2005 Chipped pine logs: A potential substrate for nursery and greenhouse crops. Proc. Southern Nursery Assn. Res. Conf. 50:112-114.

Sjöström, E. 1993. Wood chemistry: Fundamentals and applications. Academic Press, San Diego, CA.

Thorpe, V. 1973. Collaborative study of the cation exchange capacity of peat materials. J. AOAC 56:154-157.

Tripepi, R.R. 2008. What is your substrate trying to tell you? University of Idaho Extension. 17 Sept. 2011. <http://www.extension.uidaho.edu/ nursery/Landscape\%20problems/Substrate/ Chemical\%20andphysical\%20analysis.PDF>.

Tuomela, M., M. Vikman, A. Hatakka, and M. Itavaara. 2000. Biodegradation of lignin in a compost environment: A review. Bioresour. Technol. 72:169-183.

Wang, Y.T. 1998. Impact of salinity and media on growth and flowering of a hybrid Phalaenopsis orchid. HortScience 33:247-250.

Wang, Y.T. and E.A. Konow. 2002. Fertilizer source and medium composition affect vegetative growth and mineral nutrition of a hybrid moth orchid. J. Amer. Soc. Hort. Sci. 127: $442-447$.

Whipker, B.E., W.C. Fonteno, T.J. Cavins, and D.A. Bailey. 2000. Pourthru nutritional monitoring manual. NC Commercial Flower Growers' Association, Raleigh, NC.

Wright, R. 1986. The pour-through nutrient extraction procedure. HortScience 21:227-229.

Wright, R.D., J.F. Browder, and B.E. Jackson. 2006. Ground pine chips as a substrate for container-grown woody nursery crops. J. Environ. Hort. 24:181-184.

Wright, R.D., B.E. Jackson, J.F. Browder, and J.G. Latimer. 2008. Growth of chrysanthemum in a pine tree substrate requires additional fertilizer. HortTechnology 18:111-115.

Yeager, T.H., D.C. Fare, J. Lea-Cox, J. Ruter, T.E. Bilderback, C.H. Gilliam, A.X. Niemiera, S.L. Warren, T.E. Whitwell, R.D. Wright, and K.M. Tilt. 2007. Best management practices: Guide for producing container-grown plants. Southern Nurserymen's Assoc., Marietta, GA. 